ECONOMICS

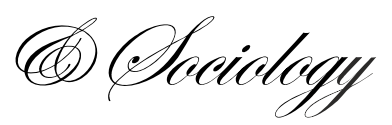

\section{EX-POST ANALYSIS OF THE EU EMISSION TRADING IN YEAR 2013 IN THE CZECH REPUBLIC}

\begin{abstract}
The main goal of the paper is to provide the first ex-post analysis of the EU ETS in year 2013 in the Czech Republic, based on the analysis of the key EU ETS sector - combustion processes. Regarding the methodology, the empirical research was used as a one part, as a second part the Mamdani fuzzy rule-based system. Since the EUA market price was low in year 2013, the Czech companies within the combustion processes group had weak motivation to trade with the EUAs. However, the revenues obtained from the EUA auctions in year 2013 were higher than revenues obtained from the environmental taxes. Moreover, auctioned EUAs had the similar characteristics as the environmental taxes. We can say that the EUA behaved as an additional carbon tax - in case that the company exceeded the level of emission limit represented by free emission allowances.
\end{abstract}

Received: March, 2015

1st Revision: May, 2015

Accepted: June, 2015

DOI: $10.14254 / 2071-$

789X.2015/8-2/13

JEL Classification: $\mathrm{H} 23, \mathrm{H} 3$, Q48, Q58
Keywords: emission trading; environmental taxation; EU ETS; Czech Republic.

\title{
Introduction
}

Generally, emission allowances trading, also called as "cap and trade program", originally started up in the USA and currently it is frequently used throughout the world. National or sub-national emission trading systems are already operating in Australia, the European Union, Japan, New Zealand, Switzerland and the United States, and are planned in Canada, China and South Korea (European Commission, 2013). Besides trading with emissions (mainly $\mathrm{CO}_{2}, \mathrm{NOx}, \mathrm{SO}_{2}$ ), there are also tradable fish quota or trading in waste sector, water protection sector and land protection sector.

The European Union established a scheme for $\mathrm{CO}_{2}$ and other greenhouse gases' emission allowances trading, the EU Emissions Trading System (EU ETS). The initial EU ETS was based on Directive 2003/87/EC, which established a fundamentally decentralized system for the pilot phase of emissions trading (2005 to 2007) and the Kyoto Protocol commitment phase (2008 to 2012). The key instruments were the National Allocation Plans 
(NAPs) (Wettestad et al., 2012). In year 2013, based on new Directive 2009/29/EC, the EU ETS came into Phase III (2013 to 2020), the post-Kyoto commitment period.

The EU ETS is substantially larger and by far more complex than the pioneering US Sulphur Allowance System (Conrad et al., 2012). The EU ETS covers more than 11,000 power stations and manufacturing plants in the $28 \mathrm{EU}$ member states as well as Iceland, Liechtenstein and Norway. Aviation operators flying within and between most of these countries are also covered. In total, around $45 \%$ of total EU emissions are limited by the EU ETS (European Commission, 2013). The EU ETS covers both European Emissions Allowances - EUAs (since 2005) and European Aviation Allowances - EUAAs (since 2012). The market price of the allowances is determined by supply and demand at the exchange. Both in the first and in the second trading period, the EU emission allowances were traded mostly on the BlueNext trading exchange. In the third trading period, there is one significant big exchange, where the auctions can be organized - European Energy Exchange EEX (EEX, 2015).

The regulatory framework of the EU ETS was largely unchanged for the first two trading periods of its operation $(2005$ - 2012); however the beginning of the third trading period in 2013 brings changes in common rules, published as Directive 2009/29/EC, which should strengthen the system. Since the EU emission allowances were previously grandfathered - for free (Wettestad et al., 2012), from year 2013 the significant yield of the emission allowances is auctioned. Grandfathering was widely criticized, mostly because it introduced significant distortions to the EU ETS (Falbo et al., 2013). Auctioning is the most transparent method of allocating allowances and puts into practice the polluter pays principle (Vicha, 2011; European Commission, 2013). Sectorial differentiation was also introduced, with (initially) far more auctioning of allowances for energy producers than energy-intensive industries. In addition, free allocations were further harmonized, to be based on common state-of-the-art technology benchmarks (Wettestad et al., 2012, p. 73). Policy makers give firms an incentive to move towards production that is less fossil-fuel intensive (Aatola et al., 2013).

In last years, $\mathrm{CO}_{2}$ emissions became also a significant member of the European commodity trading market. However, there is a fundamental difference between trading in $\mathrm{CO}_{2}$ and more traditional commodities. Sellers are expected to produce fewer emissions than they are allowed to, so they may sell the unused allowances to someone who emits more than the allocated amount. Therefore, the emissions become either an asset or a liability for the obligation to deliver allowances to cover those emissions (Benz and Trück, 2009). Regarding the EU emission allowances spot price, it fluctuated significantly both in the first and the second trading period; in the period 2005 - 2007, the EUA spot price fluctuated between 25 $\mathrm{EUR} / \mathrm{t} \mathrm{CO}_{2}$ at the beginning of the period and the nearly zero level in the end of the period. In the second trading period, the EUA spot price fluctuated in the range $6-25 \mathrm{EUR} / \mathrm{t} \mathrm{CO}_{2}$. Focusing on year 2013, the average EUA auction price was 4,4 EUR/t $\mathrm{CO}_{2}$. Regarding the whole trading period 2005 - 2013, you can see that the EUA price development shows high volatility.

Focusing on the Czech Republic, $\mathrm{CO}_{2}$ emission trading is a part of the mix of economic instruments within environmental and climate policy, precisely we can find it besides environmental taxes, charges and subsidies (Pavel and Vitek, 2012; Zimmermannova and Mensik, 2013).

In the terms of the trend in $\mathrm{CO}_{2}$ emissions per $\mathrm{KWH}$, the Czech Republic ranks on $56^{\text {th }}$ out of 178 countries (same as in 2002) and compared to European region peer set is that trend worse by $15 \%$. In the terms of the trend in carbon intensity the Czech Republic ranks on 25th (same as in 2002) and compared to European region peer set is that trend better by $15 \%$. 
Industry has been still considered for the largest polluter in the Czech Republic (Solilová and Nerudová, 2015).

The following Figure 1 shows the development of total $\mathrm{CO}_{2}$ emissions in the Czech Republic regulated by the EU ETS and the share of particular sectors of national economy regulated by the EU ETS on total $\mathrm{CO}_{2}$ emissions production in the Czech Republic regulated by the EU ETS.

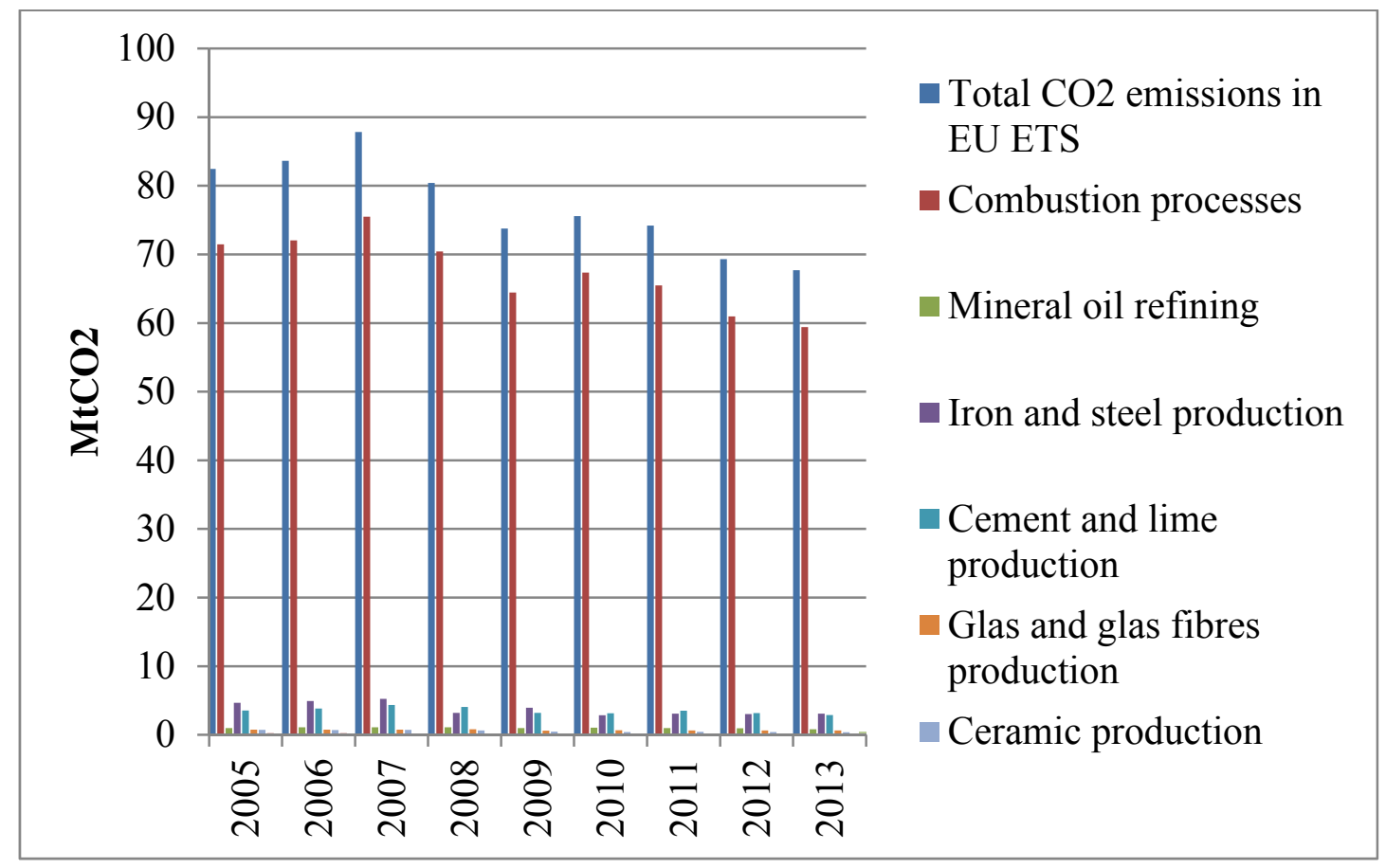

Figure 1. $\mathrm{CO}_{2}$ emissions history in the Czech Republic within the EU ETS. Source: CHMI, 2015; own work.

It is obvious, that the most significant share of $\mathrm{CO}_{2}$ emissions on total $\mathrm{CO}_{2}$ emissions production in the Czech Republic within the EU ETS has been produced by the combustion processes sector. This sector emitted almost $88 \%$ of total $\mathrm{CO}_{2}$ emissions in year 2013. You can see that the curve of total $\mathrm{CO}_{2}$ emissions within the EU ETS has similar development as the combustion processes emissions curve it self; moreover the $\mathrm{CO}_{2}$ emissions produced by the other sectors are negligible in comparison with $\mathrm{CO}_{2}$ emissions produced by combustion processes sector.

Based on the above described development of $\mathrm{CO}_{2}$ emissions in the Czech Republic, we focused our research on an empirical analysis of the behaviour of the most significant $\mathrm{CO}_{2}$ emissions producer in the Czech Republic - the combustion processes sector.

\section{Literature Overview}

Since emission allowance trading has primarily started in the US, the majority of publications dealing with tradable emission allowances assess the market for $\mathrm{SO}_{2}$ emissions under the Acid Rain Program (Benz and Trück, 2009). Regarding the EU ETS, scientists have focused mostly on modelling and forecasting the prices of $\mathrm{CO}_{2}$ emission allowances (Benz and Trück, 2009; Li et al., 2011; Conrad et al., 2012; Garcia-Martos et al., 2013; Lecuyer and Quirion, 2013), the incidence of the carbon price (Grainger and Kolstad, 2010; Cermak et al., 2015), the EUA price drivers (Aatola et al., 2013; Lutz et al., 2013), the marginal cost of both 
energy intensive companies and power sector (Lund, 2007; Chernyavska and Gulli, 2008), the influence of emission allowance trading on electricity producers (Lund, 2007; Chernyavska and Gulli, 2008; Falbo et al., 2013) or its innovation impact (Rogge et al., 2011; Rentizelas et al., 2012).

The authors of scientific papers have used various methods for their research connected with the EU ETS. We can find scientific studies, which describe particular models of EU ETS, created with different methods and different targets. For example, Li et al. (2011) used fuzzy modelling (an interval-fuzzy two stage stochastic programming model) for planning $\mathrm{CO}_{2}$ emission trading in industry systems under uncertainty, Conrad et al. (2012) used GARCH models for modelling the adjustment process of EUA's prices to scheduled macroeconomic and regulatory announcements. Aatola et al. (2013) created an equilibrium model of the emission trading market for the purposes of the EU ETS price determination, Falbo et al. (2013) created model based on the profit function for tracking of impacts of EUAs on the optimal policy of a competitive electricity producer. Garcia - Martos et al. (2013) used both ARIMA and VARIMA models for building a multivariate model for the afore mentioned prices and comparing its results with those of univariate ones, Lecuyer and Quirion (2013) created analytical and numerical model of the EU energy and carbon market for implications of the possibility of a nil carbon price on optimal policy instrument choice. Lutz et al. (2013) used Markov regime-switching GARCH model for examination of the nonlinear relationship between the EUA price and its fundamentals. Cermak et al. (2015) created broker simulation model which integrates different original soft computing and decision making methods.

Focusing on empirical studies, based on official data, questionnaire surveys and interviews, we can find particular studies in the area of the innovation impacts of the EU ETS in Germany (Rogge et al., 2011), the impacts on the investments in Sweden (Lofgren et al., 2014) or empirical ex post analyses of the EU ETS in the EU as a whole (Feng et al., 2012; Lovell et al., 2013; Martin et al., 2014).

Considering the characteristics of particular instruments of $\mathrm{CO}_{2}$ pricing, precisely emission allowances trading and environmental taxation, their impacts, efficiency and optimization, the particular economists have different opinions. The comparison and assessment of these economic instruments is not trivial, since it can be important additional source of information for policy makers in particular countries.

Dealing with the most interesting studies in this area, for example Nordhaus (2005, 2011) focused his research mainly on carbon taxation and emission allowances efficiency comparison, advantages and disadvantages of both economic instruments, and he strongly prefers taxation before emissions trading. Regarding his opinion, the fluctuations of the EUA price and its volatility within the EU ETS in one trading period is not good for investments planning. As a recommendation for the policy makers, he has proposed pure carbon taxation in the context of current fiscal policy as the most suitable instrument for greenhouse gas emissions cutting. He also suggests the consequent international harmonization of carbon taxes throughout the world as one of the policy instruments of international climate policy.

Speck (1999) also recommends carbon taxation, since there are many sources of emissions, which cannot be involved in emission allowances trading system and moreover which are considerably heterogeneous. He also emphasizes potential benefits of carbon taxes in the field of so called ,double dividend“, which can be considered as a typical argument of environmental taxation supporters (Bork, 2006, Ekins, 2007).

On the other hand, there are economists, which support emission allowances trading. For example Mansur (2013) indicates that relative to a tax, tradable permits may improve welfare in a market with imperfect competition. Moreover, based on his model of strategic and competitive behavior of wholesalers in a Mid-Atlantic electricity market, in case of 
regulators are opted to use a tax instead of permits, the deadweight loss from imperfect competition is greater.

However, Goulder (2013) for the purposes of research of climate change policy's interactions with the tax system included both a carbon tax and cap-and-trade system under the general label of "green tax", since the two environmental policies have the same features. Regarding the efficiency of "green taxes" and marginal costs of pollution abatement, we can have two different groups of "green taxes" - 1) carbon tax (revenues recycled lump-sum) and cap-and-trade, freely allocated allowances; 2) carbon tax (revenues recycled via marginal rate cuts) and cap-and-trade, auctioned allowances (revenues recycled via marginal rate cuts).

\section{The main objectives of the paper}

Currently, there is a lack of studies dealing with the impacts of the EU ETS in the Czech Republic, moreover there is no ex post analysis of the $3^{\text {rd }}$ trading period of the EU ETS with its new rules. Regarding these consequences, the main target of this paper is to provide the first ex post analysis of the EU ETS in the Czech Republic for year 2013, based on an empirical research at one side and Mamdani fuzzy rule-based system on the other side. For the purposes of this paper, 3 hypotheses are defined:

H1) Since the EUA market price was low in year 2013, the Czech companies within the combustion processes group had no motivation to trade with the EUAs on the exchange.

H2) The revenues obtained from emission allowance auctioning in year 2013 are negligible in comparison with the revenues obtained from the environmental taxes and fees in year 2013.

H3) Auctioned emission allowance had the similar characteristics as the environmental taxes and fees in the Czech Republic in year 2013.

\section{Data and methodology}

\subsection{Data}

For the purposes of this paper, we used different sources of data. At first, focusing on $\mathrm{CO}_{2}$ emission allowances price and its development, data from EEX exchange (EEX, 2015), the leading energy exchange in Europe, was used, particularly the EU emission allowances (EUAs) auction prices in particular auctioning days.

We used also data from official statistics of the Czech Republic - Czech Statistical Office (CZSO), Czech Hydrometeorological Institute (CHMI), Ministry of the Environment of the Czech Republic (MoE) and Ministry of Finance of the Czech Republic (MoF).

Regarding environmental taxes and fees in the Czech Republic, the data from current legislation was used, including particular rates of taxes and fees.

Dealing with the behavior of the companies within the combustion processes in the Czech Republic and their decision-making (see Pawliczek and Piczszur, 2013); we used 2 sources of data and information. The first data set was based on the consultations and interview with the expert from Association for the District Heating of the Czech Republic Association of Entrepreneurs in the Field of Heat Supply (ADH CR), who is responsible for the emission allowances trading. The second step of data mining and obtaining more precise data set was based on the questionnaire survey, which was focused on the key electricity and heat producers, members of working group on the EU ETS and environmental taxation within ADH CR. 


\subsection{The questionnaire survey}

The following Figure 2 shows us the yield of $\mathrm{CO}_{2}$ emissions of survey respondents on total verified $\mathrm{CO}_{2}$ emissions in the Czech Republic in the whole second trading period 2008 2012 , which is $72 \%$. You can see that it provides us sufficient information content of the questionnaire survey.

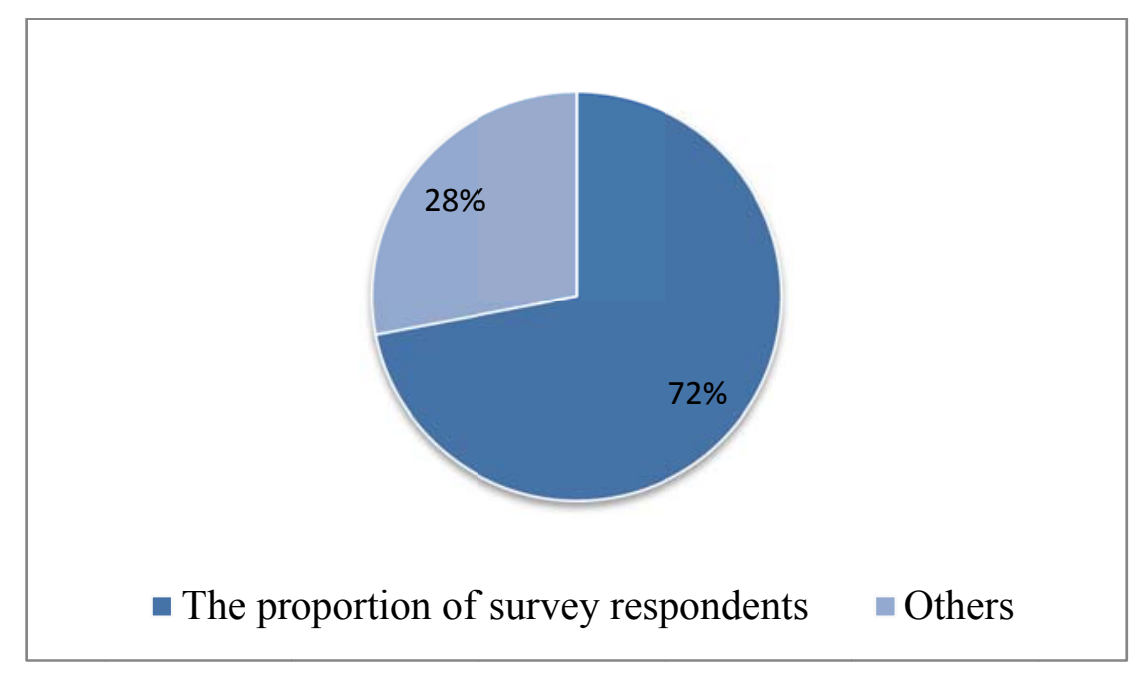

Figure 2. The yield of survey respondents

Source: own work.

For the purposes of our research, the respondents of the questionnaire survey were divided to the 3 groups based on combustion processe's size - "BS" means big source (more than $100 \mathrm{MW}$ of rated power consumption), "MS" means medium source (50-100 MW of rated power consumption) and "SS" means small source (up to $50 \mathrm{MW}$ of rated power consumption). Moreover, there are sources controlled by the same management, therefore the results of the questionnaire were analysed according to the owners of particular sources of combustion processes. In total, we have 9 general owners of particular sources, which represent 27 big sources, 6 medium sources and 9 small sources. For the purposes of the ex post analysis, we classified all owners, which have in their portfolio at least 1 big source as "BS" (totally 6 owners).

The questionnaire survey consisted of 13 questions in total, precisely 12 closed-ended questions and 1 open-ended question. The questions were focused on the following topics: purchases of additional emission allowances on the exchange for the purposes of covering of all respondent's emissions, evaluation of the EUA price as a motivation for trading or speculation on the exchange, respondents' opinion regarding the EUA price as start to think about active trading on the exchange, way of trading on the exchange, indicators with influence on emission allowances purchases and sales, evaluation of the EUA price as a motivation for starting or planning of environmental investments for the purposes of greenhouse gas emissions cutting and finally indicators with influence on planning of investments and innovations in respondent's companies.

For the purposes of this paper and for the purposes of the hypotheses evaluation, the results of selected questions will be presented. 


\subsection{The fuzzy rule-based system}

For the purposes of the electricity and heat producer's behavior and decision making analysis, fuzzy rule-based system (more details in Pokorný, 2015) was used, precisely Mamdani type of rules (Čermák and Pokorný, 2001). The Mamdani fuzzy rule-based system is defined as

$$
\begin{aligned}
& \text { IF }\left(x_{1} \text { is } A_{1,1}\right) \operatorname{AND} \ldots\left(x \text { is } A_{n}\right) \operatorname{THEN}\left(y_{1} \text { is } C_{1}\right) \\
& \operatorname{IF}\left(x_{1} \text { is } A_{1,1}\right) \operatorname{AND} \ldots\left(x \text { is } A_{n, 1}\right) \operatorname{THEN}\left(y_{2} \text { is } C_{2}\right) \\
& \ldots \\
& \text { IF }\left(x_{1} \text { is } A_{1, r}\right) \operatorname{AND~} \ldots\left(x \text { is } A_{n, r}\right) \operatorname{THEN}\left(y_{r} \text { is } C_{r}\right) .
\end{aligned}
$$

We created set of Mamdani rules for the producers within the sector of combustion processes. General rules are based on purchases or sales of the EUAs on the market. Based on Mamdani fuzzy rule-based system, we created 162 rules for the electricity and heat producer in the Czech Republic. We used the economic indicators, which can influence the behavior of the typical producers. The following economic indicators were selected on the basis of the questionnaire survey results - respondents indicated that these indicators influence their decision-making:

1. The EUA price trend development.

2. The producer situation - the current amount of available EUAs and the current $\mathrm{CO}_{2}$ emissions.

3. The environmental policy development in the CR and the EU.

4. GDP development.

There can be 3 results of behavior of the producer, precisely the following:

1. no action - the producer has no requirements on the market;

2. standard sale or standard purchase - the producer will calculate his own profit, he can trade on the market;

3. big sale or big purchase - the situation is really outstanding for the trading on the market - the producer will surely buy or sell the EUAs on the market.

The example of one Mamdani rule is the following: "IF the EUA price trend development is decrease AND the producer has EUAs for all of his $\mathrm{CO}_{2}$ emissions AND environmental policy has been tightened AND GDP development is increase THEN behavior on the market is standard purchase".

Based on defined 162 rules, the behavior of companies in the Czech Republic was generalized. We also identified and specified the "price" rules for the electricity and heat producers in the Czech Republic, also based on results of the questionnaire survey.

\section{Results}

\subsection{The behaviour of companies}

Based on the questionnaire survey results, we can say, that all respondents within the group "big sources" in the Czech Republic had to buy additional emission allowances in year 2013. Regarding small and medium sources, the answers were not the same, it depended mainly on actual covering of the emissions by the EUAs and on both policy and strategy of the management of particular companies.

Regarding the EUA price as a motivation for the trading on the exchange, 2 respondents within the group "big sources" evaluated the EUA price as motivating, 2 respondents within the group "big sources" and 1 respondent within the group "small and 
medium sources" evaluated the EUA price as rather motivating. On the other hand, 2 respondents within the group "big sources" and 2 respondents within the group "small and medium sources" evaluated the EUA price as demotivating.

A more detailed analysis shows us that the EUA price was evaluated as motivating and rather motivating by the companies, which really bought the EUAs on the exchange in year 2013. Therefore we can say that low EUA price represented for the companies motivation for the purchases on the exchange. There should be also highlighted that there was only one company in the Czech Republic, which was regularly buying the EUAs on the exchange for the purposes of speculations and which was actively trading on the exchange in year 2013 . The others were buying the EUAs only for the purposes of covering of all of their $\mathrm{CO}_{2}$ emissions.

Figure 3 shows us the levels of the EUA price, which were indicated by the respondents of the questionnaire survey as a motivation price for trading the EUAs on the exchange. The respondents particularly indicated, which price in year 2013 was motivating for purchases and which price was motivating for sales.

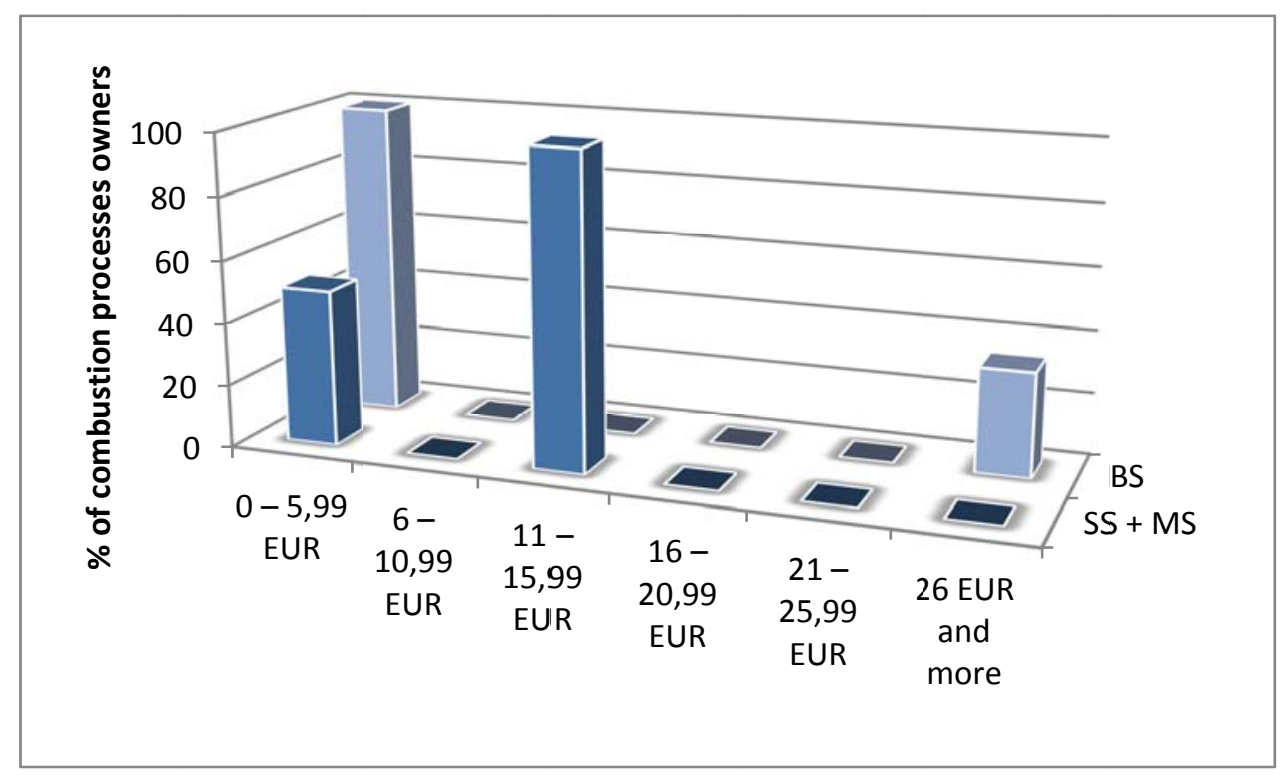

Figure 3. Purchase and sale motivation price of the EUAs in Y2013

Source: own work, based on the questionnaire survey. „BS“ means „,big sources“, „SS + MS“ means „small and medium sources“, „\% of combustion processes“" means \% from all obtained answers to this question.

The most of the respondents within the combustion processes $(100 \%$ of big sources, $50 \%$ of small and medium sources) indicated that the EUA price within the interval $0-$ 5,99 EUR/EUA represented for them a motivation for the EUA purchases on the exchange in year 2013. On the other hand, the respondents indicated that permits would sell and speculate on the exchange only if their price was higher than 11 EUR/EUA (100\% of small and medium sources), in case of big sources 26 EUR/EUA and more (33\% of respondents).

Regarding all „motivating price“ questions, nearly half of all respondents explicitly indicated that both policies and strategies of their companies did not allow them to sell or actively trade the EUAs on the exchange, they could only buy the EUAs to cover all of their $\mathrm{CO}_{2}$ emissions. Moreover, they were not allowed to speculate with the EUAs on the exchange, the rules set by their management did not allow them such behaviour. However, the answers on "motivating price" questions were obtained only from $50 \%$ of all questionnaire 
survey respondents, since the others were not allowed to answer to these kinds of questions by their top management.

Based on these findings, we can identified the "price" rules for the combustion processes in the Czech Republic, which can be expressed through Mamdani fuzzy rule-based system.

\subsection{Set of Mamdani rules for the producer in the sector of combustion processes}

At first, we should start with general rules of behavior of the producer in the sector of combustion processes in the Czech Republic within the EU ETS system. General rules will be based on purchases or sales of the EUAs on the market.

Regarding 162 basic rules for the electricity and heat producer behaviour in total, the general overview of possibilities of the producer behaviour in the Czech Republic was created. The key categories are based on different situations connected with the available amount of the EUAs and $\mathrm{CO}_{2}$ emissions in particular year. The following Table 1 summarizes the possibilities of behavior of the producer in particular situations.

Table 1. Overview of possibilities of the electricity and heat producer's behavior in CR

\begin{tabular}{|c|c|}
\hline \multicolumn{2}{|c|}{ The producer has no EUAs to cover his $\mathrm{CO}_{2}$ emissions } \\
\hline Purchase & Sale \\
\hline Mainly big and standard purchase. & No action \\
\hline \multicolumn{2}{|c|}{ The producer has EUAs to cover his $\mathrm{CO}_{2}$ emissions only partially } \\
\hline Purchase & Sale \\
\hline $\begin{array}{l}\text { Mainly standard purchase } \\
\text { Big purchase can be in the following situations } \\
\text { (one or more of them simultaneously): } \\
\text { - EUA price trend development is decrease } \\
\text { - Environmental policy has been tightened } \\
\text { - } \text { GDP development is increase }\end{array}$ & No action \\
\hline \multicolumn{2}{|c|}{ The producer has EUAs to cover all of his $\mathrm{CO}_{2}$ emissions } \\
\hline Purchase & Sale \\
\hline $\begin{array}{l}\text { Mainly no action } \\
\text { Standard purchase can be in the following } \\
\text { situations (one or more of them simultaneously): } \\
\text { - EUA price trend development is stagnation or } \\
\text { decrease; } \\
\text { - Environmental policy has been tightened or } \\
\text { unchanged; } \\
\text { - GDP development is stagnation or increase. }\end{array}$ & $\begin{array}{l}\text { Mainly no action } \\
\text { Standard sale can be in the following situations } \\
\text { (one or more of them simultaneously): } \\
\text { - EUA price trend development is stagnation } \\
\text { or increase; } \\
\text { - Environmental policy is more polluter- } \\
\text { friendly or unchanged; } \\
\text { - GDP development is stagnation or decrease; } \\
\text { - Management of company supports trading } \\
\text { and speculations. }\end{array}$ \\
\hline
\end{tabular}

Source: own work, based on consultations and the questionnaire survey.

Generally, the possibility of "sale" can be used only when the producer has enough EUAs to cover all of his emissions. Based on the questionnaire survey results, we can say, that in year 2013, there was only one producer in the sector of combustion processes in the Czech Republic, who was regular seller on the exchange. Almost all of the electricity and heat producers were only the EUAs buyers.

Based on the questionnaire survey results, we can also identify the "price" rules for the combustion processes in the Czech Republic, which can be expressed through Mamdani fuzzy 
rule-based system. The producers considered the price 0-5,99 EUR per EUA as the most suitable for their purchases. On the other hand, they would sale the EUAs only when the market price would be 11 EUR and more per EUA, moreover only when the policies and strategies of their companies would allow them to do it. So, the general "price" rules can be defined as the following Mamdani rules:

IF the EUA price is SMALL AND environmental taxes are almost constant AND the strategy of the company is rather trading friendly THEN the producer buys the EUAs only to cover his $\mathrm{CO}_{2}$ emissions;

IF the EUA price is MIDDLE AND environmental taxes are almost constant AND the strategy of the company is rather trading friendly THEN the producer buys the EUAs to cover his $\mathrm{CO}_{2}$ emissions, but starts to think about trading with the EUAs on the exchange;

IF the EUA price is HIGH AND environmental taxes are almost constant AND the strategy of the company is rather trading friendly THEN the producer buys the EUAs to cover his $\mathrm{CO}_{2}$ emissions, but starts to make his own predictions and calculations of the EUAs;

IF the EUA price is HIGHER AND environmental taxes are almost constant AND the strategy of the company is rather trading friendly THEN the producer buys the EUAs to cover his $\mathrm{CO}_{2}$ emissions, but starts to trade with the EUAs on the exchange;

IF the EUA price is THE HIGHEST AND environmental taxes are almost constant AND the strategy of the company is rather trading friendly THEN the producer buys the EUAs to cover his $\mathrm{CO}_{2}$ emissions and trades with the EUAs on the exchange.

The results of the questionnaire survey showed us the approximate values of SMALL, MIDDLE, HIGH, HIGHER and THE HIGHEST and it served us as an input to the Table 3. Regarding an explanation of these general price rules, SMALL represents approximately $0-6$ EUR/t $\mathrm{CO}_{2}$, MIDDLE represents approximately $6-8 \mathrm{EUR} / \mathrm{t} \mathrm{CO}_{2}$, HIGH represents approximately $7-9 \mathrm{EUR} / \mathrm{t} \mathrm{CO}_{2}$, HIGHER represents approximately $8-10 \mathrm{EUR} / \mathrm{t} \mathrm{CO}_{2}$ and THE HIGHEST represents more than $10 \mathrm{EUR} / \mathrm{t} \mathrm{CO}_{2}$. The following Figure 4 shows us the behavior of Czech producer in the sector of combustion processes in year 2013 in graphical expression. Since the Figure 4 is based on fuzzy rules, the frontiers between particular EUA prices are not sharp, but blurred.

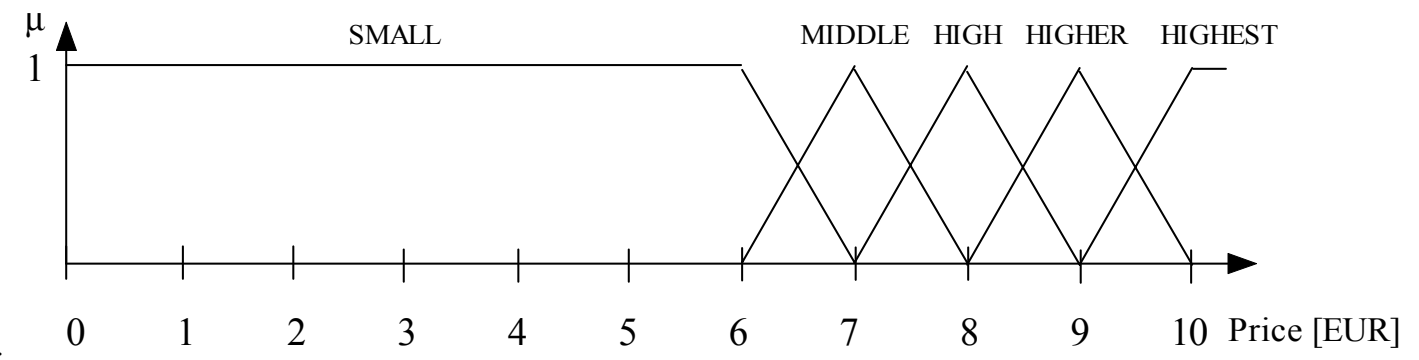

Figure 4. Shapes of Membership Functions for Given Input Variable Price Source: own work.

Focusing on the EUA market price development, the following Figure 5 shows us the development of the EUA auction price in year 2013. The red line represents the level 6 EUR/EUA, when the producers start to think about more active trading with the EUAs on the exchange (not only purchases for the purposes of covering all $\mathrm{CO}_{2}$ emissions). The red line 6 EUR/EUA represents also the middle level in the previous Figure 4. 


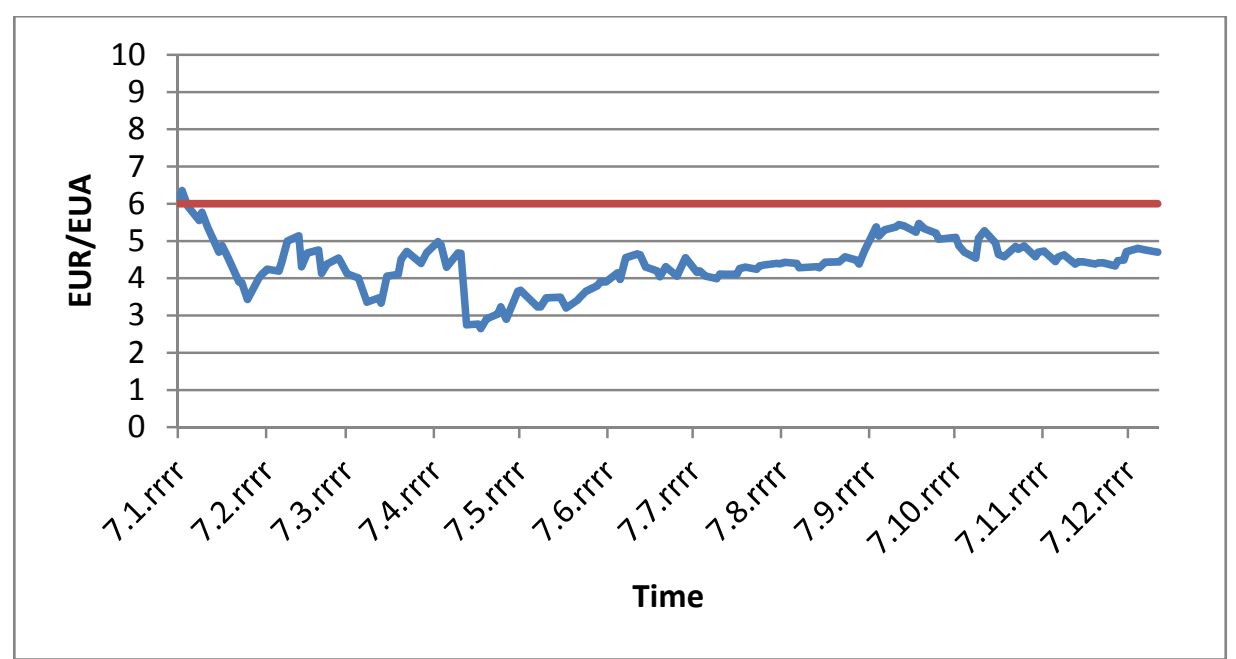

Figure 5. The EUA Auction Price in Y2013

Source: EEX, 2015; own work.

We can see, that the EUA auction price in year 2013 fluctuated in the interval 6,18 EUR/EUA (7.1.2013) and 2,75 EUR/EUA (18.4.2013), where only 2 auction days represent the auction price higher than 6 EUR/EUA. Comparing Figure 5 with Figure 4, it is obvious, that the electricity and heat producers in the Czech Republic evaluated the EUA price as small in year 2013 and therefore participated on the market only in the role of the buyers - usually bought the EUAs only to cover all of their $\mathrm{CO}_{2}$ emissions.

\subsection{Comparison of characteristics of the EUAs and environmental taxes}

For the purposes of the comparison of the EU ETS and environmental taxation in year 2013 in the Czech Republic, we selected the following characteristics: emission's price in Y2013, behaviour of the companies on the market, budgetary determination of revenues, regulated emissions and the primary price impact.

We can compare the average EUA auction price in year 2013 with air protection fees' rates (imposed on $\mathrm{SO}_{2}$, NOx, VOC and $\mathrm{PM}$ emissions) and $\mathrm{CO}_{2}$ tax proposal (revision of 2003/96/EC Directive). The following Figure 6 shows us the comparison of all tax rates, charges and emissions' prices in year 2013. However, the energy taxes are missing, since their tax rates are not directly imposed on pollution.

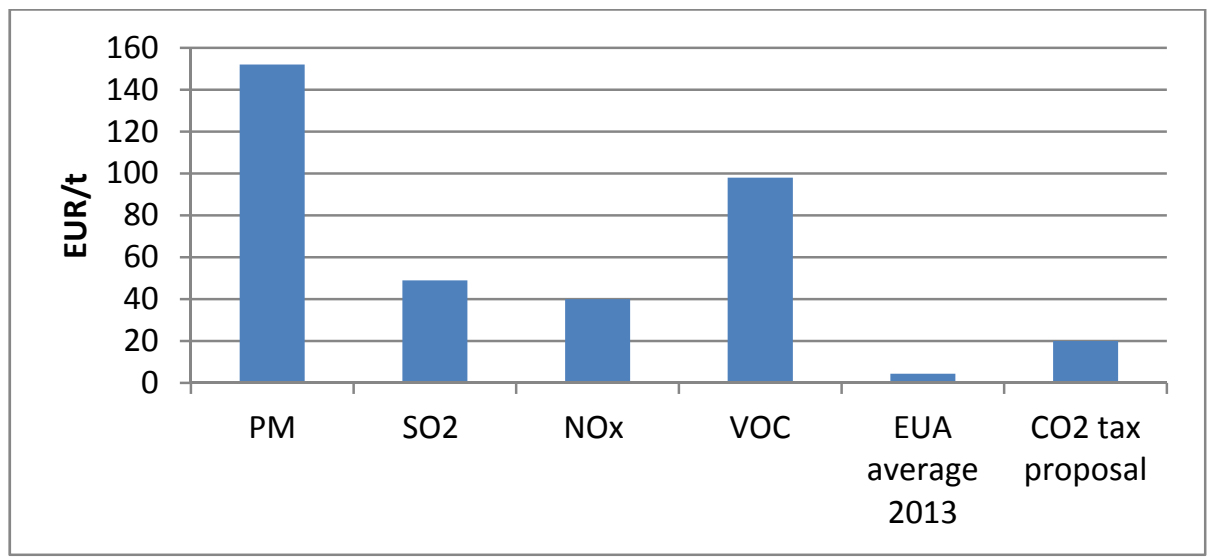

Figure 6. Comparison of the particular pollutant's prices in CR in Y2013

Source: Zimmermannova and Cermak, 2015. 
You can see, that the average EUA auction price in year 2013 (4,4 EUR per ton of $\mathrm{CO}_{2}$ ) is much more lower than all of the fees imposed on other pollutants in air protection area in the Czech Republic, relative to the tonne of particular pollutant; moreover it is lower than $\mathrm{CO}_{2}$ tax proposed in revision of Directive 2003/96/EC (20 EUR per ton of $\mathrm{CO}_{2}$ ). However, we should focus also on revenues obtained from the EUA auctions, air protection fees and general energy taxation, based on current Directive 2003/96/EC. The following Figure 7 shows the comparison of all revenues from environmental taxes and charges in the Czech Republic in year 2013. Focusing on total revenues obtained from the EUA auctions, air protection fees and general environmental taxation, based on current 2003/96/EC directive, we obtained rather interesting results.

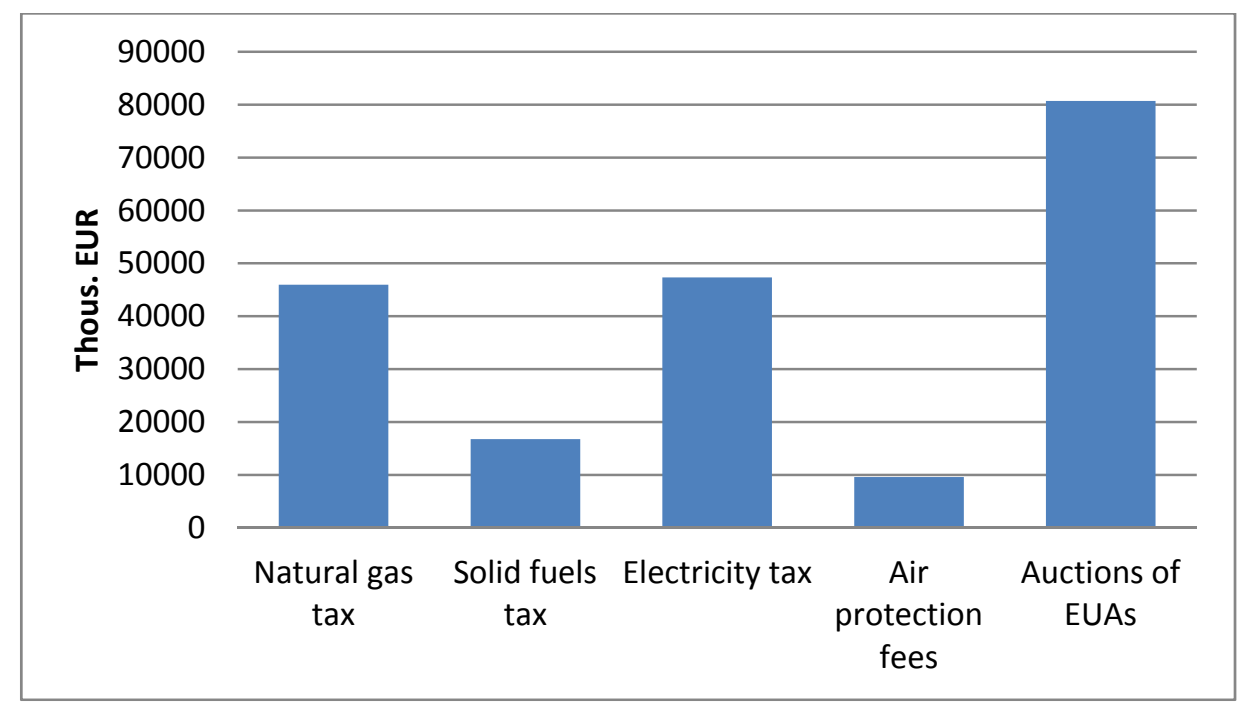

Figure 7. Environmental taxes and EUA auction's revenues in CR in Y2013 Source: Zimmermannova and Cermak, 2015.

It is obvious, that contrary to the lowest "emission price", the revenues from the EUA auctions in year 2013 were higher than revenues obtained from all of the air protection fees; furthermore it exceeded revenues obtained from particular energy taxes - natural gas tax, solid fuel tax and electricity tax. We can say that the auctioned EUAs were important source of public budgets revenues in the Czech Republic in year 2013.

Focusing on budgetary determination of these revenues, the following Table 2 shows us the distribution of $50 \%$ of total auctions revenues. The rest of the auction revenues come to the general state budget.

Table 2. Distribution of $50 \%$ of Total Auctions Revenues

\begin{tabular}{lcc}
\hline Period & State Environmental Fund & Ministry of Industry and Trade \\
\hline 2013 & $100 \%$ & $0 \%$ \\
\hline $2014-2015$ & $65 \%$ & $35 \%$ \\
\hline $2016-2020$ & $60 \%$ & $40 \%$ \\
\hline
\end{tabular}

Source: Current legislation; own work.

You can see, that in year 2013, all additional revenues obtained from the auctions (the EUA auctions on behalf of the Czech Republic) were partially the income partially of the State Environmental Fund and partially of the general state budget. It is the same as in case of 
environmental taxes and fees in the Czech Republic. In year 2014, there is another one receiver of the total auction revenues - Ministry of Industry and Trade of the Czech Republic.

The following Table 3 summarizes particular characteristics of the EUAs, environmental taxes and emission fees in year 2013 in the Czech Republic and focuses on their comparison.

Table 3. The comparison of characteristics in year 2013

\begin{tabular}{|c|c|c|c|}
\hline & EUA - auctions & Energy taxes & Emission fees \\
\hline Emission price, tax rate & $\begin{array}{l}\text { Floating - based on market } \\
\text { development }\end{array}$ & $\begin{array}{l}\text { Fixed - based on } \\
\text { 2003/96/EC }\end{array}$ & $\begin{array}{l}\text { Fixed - based on } \\
\text { national legislation }\end{array}$ \\
\hline $\begin{array}{l}\text { Trading - auctions, } \\
\text { secondary market }\end{array}$ & $\begin{array}{l}\text { EUA price }<6 \text { EUR almost } \\
\text { only purchase } \\
\text { EUA price }>10 \text { EUR } \\
\text { possibility of sale }\end{array}$ & No & No \\
\hline $\begin{array}{l}\text { The key role of } \\
\text { companies }\end{array}$ & The EUA price payer & Tax payer & Fee payer \\
\hline $\begin{array}{l}\text { Budgetary } \\
\text { determination of } \\
\text { revenues }\end{array}$ & $\begin{array}{l}\text { General state budget, State } \\
\text { Environmental Fund }\end{array}$ & $\begin{array}{l}\text { General state } \\
\text { budget }\end{array}$ & $\begin{array}{l}\text { State Environmental } \\
\text { Fund }\end{array}$ \\
\hline Emissions & $\mathrm{CO}_{2}$ and ekv. & $\begin{array}{l}\text { Mixture of } \\
\text { emissions }\end{array}$ & $\mathrm{SO}_{2}, \mathrm{NO}_{\mathrm{x}}, \mathrm{VOC}, \mathrm{PM}$ \\
\hline Payer & Companies & $\begin{array}{l}\text { Companies, } \\
\text { households }\end{array}$ & Companies \\
\hline Primary incidence & Energy product's prices & $\begin{array}{l}\text { Energy product's } \\
\text { prices }\end{array}$ & $\begin{array}{l}\text { Energy product's } \\
\text { prices }\end{array}$ \\
\hline
\end{tabular}

Source: Current legislation; own work.

Since the rules of the EU ETS changed and the total amount of the EUAs for companies is no more entirely for free, the companies are more interested in the EU ETS and pay attention on their own predictions and calculations of the EUAs prices.

Regarding trading on the exchange, we can say, that the low EUAs price in year 2013 represented weak motivation for the electricity and heat producers in the Czech Republic to trade on the exchange. Generally, the companies were almost entirely buyers on the exchange, they were willing to sale the EUAs only if its price was higher than 10 EUR. Focusing on the other characteristics, it is obvious, that the EUAs and environmental taxes in the Czech Republic had similar characteristics in year 2013, precisely in the area of the role of companies (producers), budgetary determination of revenues and primary price impact.

However, focusing on addressing emissions, there was a difference, of course, since the Czech Republic had no direct carbon taxes in year 2013.

\section{Discussion}

Based on the consultations and interview with the EU ETS expert from Association for the District Heating of the Czech Republic - Association of Entrepreneurs in the Field of Heat Supply and the results of the questionnaire survey, we can say that the emission allowances represent in the Czech Republic an important environmental policy instrument, which can influence strategies and investments of all companies involved in the EU ETS. 
Since the EU ETS changed, the companies are more interested in it and pay attention on their own predictions and calculations of the EUAs prices. They also calculate with the EUAs in their medium-term plans and investments decisions.

Focusing on our three hypotheses, we can conclude the following:

H1) Since the EUA market price was low in year 2013, the Czech companies within the combustion processes group had no motivation to trade with the EUAs on the exchange.

Based on our ex-post analysis, we can partially confirm this hypothesis. Since the EUA auction price was higher than 6 EUR/EUA only in 2 auction days in 2013 (see Figure 4), the most of the Czech companies evaluated the EUA price as small and therefore was on the market only in the role of the buyer - usually bought the EUAs only to cover all of their $\mathrm{CO}_{2}$ emissions. Based on the questionnaire survey, we can say that in year 2013 in the Czech Republic, there was only one producer within the combustion processes, which regularly traded on the exchange and sold the EUAs. Almost all of the electricity and heat producers were only the EUAs buyers.

H2) The revenues obtained from emission allowance auctioning in year 2013 are negligible in comparison with the revenues obtained from the environmental taxes and fees in year 2013.

Based on our ex-post analysis, we can reject this hypothesis. Although the average $\mathrm{CO}_{2}$ emission "price" in year $2013\left(4,4\right.$ EUR per ton of $\left.\mathrm{CO}_{2}\right)$ was lower than all of the fees imposed on other pollutants in air and climate protection area, the revenues from the EUA auctions in year 2013 were higher than all of the revenues obtained from all of the air protection fees and revenues obtained from general energy taxes - natural gas tax, solid fuel tax and electricity tax. We can say, that the auctioned EUAs are currently important source of public budgets revenues. Moreover, it is evident, that this kind of revenues will be more important depending on increasing share of total EUAs determined for auctions. It supports also Ekins and Speck conclusion (2011), that the decision to auction from 2013 the majority (and by 2027 100\%) of the EU ETS emission allowances means that governments will have a new source of environment-related revenues.

H3) Auctioned emission allowance had the similar characteristics as the environmental taxes and fees in the Czech Republic in year 2013.

Based on our ex-post analysis, we can partially confirm this hypothesis. It is obvious, that if the EUA market price was lower than 6 EUR per ton than it behaved almost entirely as a carbon tax or fee. The companies only "paid for $\mathrm{CO}_{2}$ emissions", they did not use the EUA as a "commodity" for trading. Therefore the EUA behaved as an additional carbon tax or fee in case that the company exceeded the level of emission limit represented by free emission allowances. Moreover, the budgetary determination of revenues obtained from auctions was in year 2013 the same as in case of environmental taxes and fees in the Czech Republic General state budget and State Environmental Fund.

Besides the subject of particular economic instruments - particular emissions of $\mathrm{CO}_{2}$, $\mathrm{NOx}, \mathrm{SO}_{2}$, VOC and PM, and consequently mix of emissions under the energy taxation, the significant difference between emission trading and environmental taxation in the Czech Republic in year 2013 can be visible in the "floating tax rate".

There should be also highlighted Goulder's idea: "I will include both a carbon tax and cap-and-trade system under the general label of "green tax", since the two environmental policies have the same features" (Goulder, 2013). Based on the above described ex post analysis, we can say that in the Czech Republic in year 2013, these two economic instruments of the environmental policies had similar features.

Based on Ekins and Speck research (2011), it has long been recognized that an auctioned environmental trading scheme has much in common with an environmental tax (Ekins and Speck, 2011, p. 354). Based on their research, it seems logical to include in the 
definition of a possible environmental tax reform not only revenues generated from energy and environmental taxation, but also those resulting from the auctioning of the EU ETS emission allowances.

It is important, that the companies within the combustion processes group understood the EU ETS much more as an additional environmental tax or fee, so the EUAs can represent additional costs for them. It is necessary to realize changing economic situation and business conditions of particular companies. Companies are constantly under pressure of reducing costs and finding of cost reserves. This is result of global expansion and developing Information Society, which asks still new requirements. That has important impact to structure of performed activities and so to structure and development of different cost groups. That causes problems and difficulties with theirs appropriate and exact allocation in relation to performance of production (more in Popesko, 2013 or Novák and Popesko, 2014).

Moreover, small and medium sources of pollution represent also small and medium enterprises (SME), which are more sensitive to changes within external environment because of their size. In longer term period, discussion about SMEs problems is focused on issue of levies, quality of legal system and support of SMEs by government. For optimal functioning of the economic system, optimism of its participants is very important (Belas et al., 2014). Therefore the right and long term setting of the EU ETS rules is very important.

Naturally, the EU ETS is constantly developing and changing and the behaviour of particular companies in the Czech Republic can also change in the following years. The next development of the behaviour of particular stakeholders of the EU ETS in the Czech Republic will be the object of our future research, simultaneously with possible analyses and recommendations for particular policy makers.

\section{Conclusions}

The results of this ex post analysis of the EU ETS show us, that the behaviour of the Czech companies is slightly different from policy makers' expectations. Focusing on the behaviour of particular companies within the EU ETS in year 2013 in more details, it is obvious, that the most of them evaluated the EUA price as small and therefore was on the market only in the role of the buyers - usually bought the EUAs only to cover all of their $\mathrm{CO}_{2}$ emissions.

What is also important, the EUA price in year 2013 did not motivate the companies within the combustion processes sector to realize additional investments or technological adjustments for the purposes of $\mathrm{CO}_{2}$ emissions cutting.

Regarding the public finance consequences, the auctioned EUAs were important source of public budgets revenues in the Czech Republic in year 2013. Moreover, it is evident, that this kind of revenues will be important mainly in next years, depending on increasing share of total EUAs determined for auctions within the EU ETS. We can say that the characteristics of $\mathrm{CO}_{2}$ emission allowances and environmental taxation in the Czech Republic were more similar in year 2013 than in the previous trading periods.

The results of this ex post analysis can serve as an additional source of information for policy makers both in the Czech Republic and the EU; it can be valuable mainly for the purposes of the current economic instruments of the environmental, energy and climate policy adjustments.

\section{Acknowledgments}

This research was supported by the grant No. P403/12/1811 provided by the Czech Science Foundation. 


\section{References}

Aatola, P., Ollikainen, M., Toppinen, A. (2013), Price determination in the EU ETS market: Theory and econometric analysis with market fundamentals, Energy Economics, 36, March 2013, pp. 380-395.

Belás, J., Macháček, J., Bartoš, P., Hlawiczka, R., Hudáková, M. (2014), Business Risks and the Level of Entrepreneurial Optimism among SME in the Czech and Slovak Republic, Journal of Competitiveness, 6 (2), pp. 30-41, DOI: 10.7441/joc.2014.02.03.

Benz, E., Trück, S. (2009), Modeling the Price Dynamics of CO2 Emission Allowances, Energy Economics, 31 (1), pp. 44-15.

Bork, C. (2006), Distributional Effects of the Ecological Tax Reform in Germany: an Evaluation with a Microsimulation Model, in: Serret, Y., Johnstone, N. The Distributional Effects of Environmental Policy, 1 st edition, Cheltenham, UK: Edward Elgar, 2006, pp. 139-170. OECD. ISBN 978-1-84542-3.

Cermak, P., Pokorny, M. (2001), An Improvement of Non-Linear Neuro-Fuzzy Model Properties, in: Neural Network World, ICS AV CR, Prague, CZ, 11 (5), 2001, pp. 503 523.

Cermak, P., Zimmermannova, J., Lavrincik, J., Pokorny, M., Martinu, J. (2015), The Broker Simulation Model in the Emission Allowances Trading Area, International Journal of Energy Economics and Policy, 2015, 5(1), pp. 80-95.

Chernyavska, L., Gulli, F. (2008), Marginal $\mathrm{CO}_{2}$ cost pass-through under imperfect competition in power markets, Ecological Economics, 68, December 2008, pp. 408-421.

CHMI (2015), Emissions of Greenhouse Gases, [online]. [cit. 2015-07-14]. WWW: < http://portal.chmi.cz/files/portal/docs/uoco/isko/grafroc/13groc/gr13cz/tab/tabX3_CZ.ht $\mathrm{ml}>$.

Conrad, C., Rittler, D, Rotfuß, W. (2012), Modeling and explaining the dynamics of European Union Allowance prices at high-frequency, Energy Economics, 2012, 34, January 2012, pp. 316-326.

EEX (2015), EU Emission Allowances - Prices and Trading Volumes, [online]. [cit. 2015-07$14]$.

WWW:

$<$ https://www.eex.com/en/Market\%20Data/Trading\%20Data/Emission\%20Rights $>$.

Ekins, P. (2007), The Effects of ETR on Competitiveness: Modelling with E3ME, COMETR WP 4 Policy Brief, Final COMETR Workshop, 21.3.2007, Bruxelles.

European Commission (2013), The EU Emissions Trading System (EU ETS), European Union, October 2013. [online]. [cit. 2015-03-10]. WWW: < http://ec.europa.eu/clima/publications/docs/factsheet_ets_en.pdf $>$.

Falbo, P., Felletti, D., Stefani, S. (2013), Free EUAs and fuel switching, Energy Economics, 2013, 35, January 2013, pp. 14-21.

Feng, Z. H., Wei, Y. M., Wang, K. (2012), Estimating risk for the carbon market via extreme value theory: An empirical analysis of the EU ETS, Applied Energy, 2014, 99, pp. $97-$ 108.

García-Martos, C., Rodríguez, J., Sánchez, M. J. (2013), Modelling and Forecasting Fossil Fuels, $\mathrm{CO}_{2}$ and Electricity Prices and their Volatilities, Applied Energy, 101, January 2013, pp. 363-375.

Goulder, L. H. (2013), Climate change policy's interactions with the tax system, Energy Economics, 2013, 40, pp. 3-11.

Grainger, C. A., Kolstad, C. D. (2010), Who Pays a Price on Carbon? Environmental and Resource Economics, 46 (3), pp. 359-376.

Lecuyer, O., Quirion, P. (2013), Can Uncertainty Justify Overlapping Policy Instruments to Mitigate Emissions? Ecological Economics, 93, September 2013, pp. 177-191. 
Li, M. W., Li, Y. P., Huang, G. H. (2011), An Interval-Fuzzy Two-Stage Stochastic Programming Model for Planning Carbon Dioxide Trading under Uncertainty, Energy, 2011, 36 (9), pp. 5677-5689.

Lofgren, A., Wrake, M., Hagberg, T., Roth, S. (2014), Why the EU ETS needs reforming: an empirical analysis of the impact on company investments, Climate Policy, 2014, 14 (5), pp. 537-558.

Lovell, H., Bebbington, J., Larrinaga, C., De Aguiar, T.R.S. (2013), Putting carbon markets into practice: a case study of financial accounting in Europe, Environment and Planning C-Government and Policy, 31(4), pp. 741-757.

Lund, P. (2007), Impacts of EU carbon emission trade directive on energy-intensive industries - Indicative micro-economic analyses, Ecological Economics, 63, September 2007, pp. 799-806.

Lutz, B. J., Pigorsch, U., Rotfuß, W. (2013), Nonlinearity in cap-and-trade systems: The EUA price and its fundamentals, Energy Economics, 40, November 2013, pp. 222-232.

Mansur, E. T. (2013), Prices versus quantities: environmental regulation and imperfect competition, Journal of Regulatory Economics, 2013, 44 (1), pp. 80-102.

Martin, R., Muuls, M., De Preux, L. B., Wagner, U. J. (2014), On the empirical content of carbon leakage criteria in the EU Emissions Trading Scheme, Ecological Economics, 2014, 105, pp. 78-88.

Ministry of Finance of the Czech Republic (MoF) (2014), Monitor. [online]. [cit. 2014-0930]. WWW: <http://monitor.statnipokladna.cz/en/2013/>.

Ministry of the Environment of the Czech Republic (MoE) (2014), Internal material, Department of Energy and Climate Protection.

Nordhaus, W. D. (2005), Life after Kyoto: Alternative Approaches to Global Warming Policies, National Bureau of Economic Research. Working paper 11889.

Nordhaus, W. D. (2011), The Architecture of Climate Economics: Designing a Global Agreement on Global Warming, Bulletin of the Atomic Scientists, 2011, 67 (1), pp. 9-18.

Novák, P., Popesko, B. (2014), Cost Variability and Cost Behaviour in Manufacturing Enterprises, Economics and Sociology, 7 (4), pp. 89-103.

Pavel, J., Vitek, L. (2012), Transaction costs of environmental taxation: the administrative burden, in: Milne, J. E., Andersen, M. S. (eds.) Handbook of Research on Environmental Taxation, Edward Elgar Pub, 2012, pp. 273-282. ISBN 978-1-84844997-8.

Pawliczek, A., Piszczur, R. (2013), Effect of Management Systems ISO 9000 and ISO 14000 on Enterprises' Awareness of Sustainability Priorities, $E+M$ Economics and Management, 2013, 16 (2), pp. 66-79.

Pokorný, M. (2015), Complex Systems Modelling Using Extended Fuzzy Non-Linear Regression Analysis, EMI (Economics Management Innovation), 7 (1), 2015, pp. 13-21.

Popesko, B. (2013), Costing Methods Utilization in Czech Enterprises, International Journal of Entrepreneurial Knowledge, 2013, 1(1), pp. 38-45.

Rentizelas, A. A., Tolis, A. I., Tatsiopoulos, I. P. (2012), Investment planning in electricity production under $\mathrm{CO}_{2}$ price uncertainty, International Journal of Production Economics, 140(2), pp. 622-629.

Rogge, K. S., Schneider, M., Hoffmann, V. H. (2011), The innovation impact of the EU Emission Trading System - Findings of company case studies in the German power sector, Ecological Economics, 70, January 2011, pp. 513-523.

Solilova, V., Nerudova, D. (2015), Evaluation of Greenhouse Gas Emissions and Related Aspects: Case of the Czech Republic, Acta Universitatis Agriculturae et Silviculturae Mendelianae Brunensis, 63(1), pp. 281-292. 
Speck, S. (1999), Energy and Carbon Taxes and Their Distributional Implications, Energy policy, 1999, 27, pp. 659-667.

Vicha, O. (2011), The Polluter-Pays Principle in the OECD Recommendations and its Aplication in the International and EC/EU Law, Czech Yearbook of Public \& Private International Law, Prague: Czech Society of International Law, 2011, 2, pp. 57-67.

Wettestad, J., Eikeland, P. O., Nilsson, M. (2012), EU Climate and Energy Policy: A Hesitant Supranational Turn? Global Environmental Politics, 2012, 12 (2), pp. 65-84.

Zimmermannova, J., Cermak, P. (2015), Emission allowances trading vs. environmental taxation: the case study of Czech Republic, Actual Problems of Economics, 163 (1), pp. 328-337.

Zimmermannova, J., Mensik, M. (2013), Ex-Post Analysis of Solid Fuels, Natural Gas and Electricity Taxation Introduction, Politicka ekonomie, 2013, 61 (1), pp. 46-66. 